\title{
Terkendalanya Proses Implementasi Kartu Jakarta Sehat (KJS)
}

\author{
Gugum Mukdas Sudarjah \\ Program Studi Studi Pembangunan, \\ Sekolah Arsitektur, Perencanaan dan \\ Pengembangan Kebijakan (SAPPK) \\ Institut Teknologi Bandung \\ E-Mail: zummymukdas@yahoo.co.id
}

\author{
Abdul Maqin \\ Fakultas Ekonomi \\ Universitas Pasundan Bandung \\ J1. Tamansari No.6-8 Bandung, 40116 \\ E-Mail: a_maqin@yahoo.com
}

\begin{abstract}
Limited access to health care received by the poor citizens in Jakarta during the period of the previous administration to be one of the issues raised by Jokowi-Ahok to attracts the sympathy citizens of Jakarta in the election of Governor and Deputy Governor of the period 2012-2017, through the Jakarta Health Card (KJS) Jokowi Ahok makes serious effort to improve standards for people in the healthcare sector. Problems appear when the Jakarta Health Card program was launched, the citizen's euphoria towards free treatment creates an impact on increasing patient Jakarta Health Card users. Limitations of medical infrastructure (health centers and Referral Hospital), they cause the disruption of the implementation of public policy in the health sector through the program launched. The purpose of this study was to analyze the problems of implementation of the Jakarta Health Card (KJS) does not function as expected. The method used is to use the approach method Institutional Analisys Development (IAD). The results obtained in this study is the problem of the procurement of Public services does not always work as expected many factors that cause it, in the case of the implementation of the Jakarta Health Card (KJS) constraints derived from the behavior of poor people in treatment as well as medical facilities and infrastructure are available.
\end{abstract}

Keywords: Jakarta Health Card, public policy, Institutional Analisys Development

\begin{abstract}
ABSTRAK
Keterbatasan akses kesehatan yang diterima oleh masyarakat miskin di Jakarta pada periode pemerintahan sebelumnya menjadi salah satu isu yang diangkat oleh Jokowi-Ahok untuk menarik simpati warga masyarakat Jakarta dalam Pemilihan Gubernur dan Wakil Gubernur periode 2012-2017, melalui program Kartu jakarta Sehat (KJS) Jokowi-Ahok berupaya untuk meningkatkan taraf hidup masyarakat di bidang kesehatan. Permasalahan muncul ketika program Kartu Jakarta Sehat diluncurkan, euforia masyarakat terhadap pengobatan gratis berdampak kepada meningkatnya pasien pengguna Kartu Jakarta Sehat. Keterbatasan sarana dan prasarana medis (Puskesmas dan Rumah Sakit Rujukan) menjadi faktor penyebab dari terganggunya implementasi kebijakan publik di bidang kesehatan melalui progam yang dicanangkan tersebut. Tujuan penelitian ini adalah untuk mengurai permasalahan implementasi Kartu Jakarta Sehat (KJS) tidak berjalan sesuai yang diharapkan. Adapun metode yang digunakan adalah dengan menggunakan pendekatan metode Institutional Analisys Development (IAD). Hasil yang diperoleh dalam penelitian ini adalah permasalahan penyelenggaran pelayanan publik selalu tidak berjalan sesuai yang diharapkan banyak faktor yang menyebabkannya, dalam kasus implementasi Program Kartu Jakarta Sehat (KJS) kendala tersebut berasal dari perilaku masyarakat miskin dalam berobat serta keterbatasan sarana dan prasarana medis yang tersedia.
\end{abstract}

Kata Kunci: Kartu Jakarta Sehat, Kebijakan Publik, IAD. 


\section{PENDAHULUAN}

Kartu Jakarta Sehat menjadi salah satu gebrakan awal sebagai sebuah instrumen kebijakan publik dibidang kesehatan yang dilakukan oleh JokowiAhok setelah dilantik sebagai Gubernur dan Wakil Gubernur Provinsi DKI Jakarta terpilih.

Program KJS bukanlah satu-satunya inovasi kebijakan publik dalam bidang kesehatan yang diselenggarakan pemerintah daerah di Indonesia. Di beberapa daerah telah banyak dilakukan inovasi-inovasi kebijakan pelayanan kesehatan bagi masyarakat, seperti penelitian Septyandrica dan Ardhyanti (2009) menjelaskan beberapa inovasi kebijakan publik dalam bidang kesehatan yang dilakukan di beberapa daerah seperti di Purbalingga, Jogyakarta, dan Solo. Programprogram kesehatan yang diluncurkan bervariatif, salah satunya adalah Program JPSBK di Purbalingga pada tahun 2001, yang dikelola oleh lembaga berupa Badan Penyelenggara (Bapel), dengan membagi peserta menjadi tiga kelompok, yaitu miskin, para miskin, dan non miskin. Di Jogyakarta menambahkan kelompok khusus penerima layanan, yaitu kelompok rentan miskin seperti PKK, RT/RW, ibu hamil, dan penderita penyakit tertentu.

Dalam Undang-undang Nomor 32 Tahun 2004, Otonomi Daerah diartikan sebagai berpindahnya wewenang kepala daerah otonom untuk mengatur dan mengurus urusan pemerintahan dari pemerintah pusat dan kepentingan masyarakat setempat menurut prakarsa sendiri berdasarkan aspirasi masyarakat sesuai dengan peraturan perundang-undangan. Negara Republik Indonesia sebagai negara kesatuan menganut asas desentralisasi dalam penyelenggaraan pemerintahan, dengan memberikan kesempatan dan keleluasaan kepada daerah untuk menyelenggarakan otonomi daerah. Kebijakan desentralisasi yang diwujudkan dalam pembentukan daerah otonom dan penyelenggaraan otonomi daerah diarahkan untuk mempercepat terwujudnya kesejahteraan masyarakat. Salah satu azas yang dianut dalam Otonomi daerah adalah azas dekonsentrasi, di mana terdapat pelimpahan wewenang pemerintahan oleh Pemerintah kepada Gubernur sebagai wakil pemerintah dan/atau kepada instansi vertikal di wilayah tertentu.

Sistem otonomi daerah menempatkan manusia sebagai objek dan subjek pembangunan. Hal ini dapat dilihat dari perubahan sentralisasi kekuasaan menjadi desentralisasi. Di mana pembangunan yang top down diubah menjadi pembangunan berbasis masyarakat (botton up). Masyarakat diberi peluang untuk berpartisipasi dalam berbagai aspek guna kemajuan negara dan daerahnya (Silfia dan Abdul Aziz, 2009).

Oleh karena itu, diharapkan dari adanya perubahan paradigma pemerintahan otonomi daerah dengan sistem desentralisasi akan mendorong para kepala daerah untuk meningkatkan kualitas pelayanan kepada masyarakat sebagai bentuk respon atas terpilihnya kepala daerah dengan proses pemilihan kepala daerah secara langsung oleh masyarakatnya. Di satu sisi, menumbuhkan faktor-faktor kunci dan menciptakan inovasi yang bisa mendorong perbaikan kebijakan dan perbaikan kesejahteraan warga adalah salah satu tantangan dalam desentralisasi (Triwibowo, Muhajir dan Mutasya, 2010).

Selain itu, dipelukan figur dan visi yang tegas dari kepala daerah dalam upaya untuk memajukan daerahnya dan memperjuangkan aspirasi dari masyarakat yang telah memilihnya yang dituangkan kedalam program kerja selama periode kepemimpinannya.

Jika menilai kepada misi yang diusung pasangan Jokowi-Ahok dalam periode pemerintahannya, yaitu: 1) mewujudkan Jakarta sebagai kota modern yang tertata rapi serta konsisten dengan rencana tata ruang wilayah, 2) menjadikan Jakarta sebagai kota yang bebas dari masalah-masalah menahun seperti macet, banjir, pemukiman kumuh, sampah, dan lain-lain, 3) menjamin ketersediaan hunian dan ruang publik yang layak serta terjangkau bagi warga kota dan ketersediaan pelayanan kesehatan yang gratis sampai rawat inap dan pendidikan yang berkualitas secara gratis selama dua belas tahun untuk warga Jakarta; 4) membangun budaya masyarakat perkotaan yang toleran, tetapi juga sekaligus memiliki kesadaran dalam memelihara kota, dan 5) membangun pemerintahan yang bersih dan transparan serta berorientasi pada pelayanan publik (www.jakarta.go.id).

Berdasarkan kepada misi yang diemban selama lima tahun kepemimpinannya, hampir seluruhnya berfokus kepada peningkatan kualitas pelayanan publik. Meski dalam rumusannya tak satu pun menyebut "hak asasi manusia", namun sangat jelas bahwa misi ini sarat dengan komitmen penghormatan, 
perlindungan, dan pemenuhan hak asasi manusia (HAM), baik hak sipil maupun, terutama, hak ekonomi, sosial, dan budaya.

Salah satu yang menonjol adalah realisasi program Kartu Jakarta Sehat. Dalam usaha memenuhi hak atas kesehatan warganya, Pemerintah Provinsi DKI Jakarta (Pemprov DKI) meluncurkan program Kartu Jakarta Sehat pada 10 November 2012. Lewat program ini, biaya pengobatan bagi warga Jakarta di Puskesmas dan rawat inap kelas tiga di Rumah Sakit Umum Daerah (RSUD) maupun rumah sakit swasta yang menjadi rekanan Pemprov DKI ditiadakan.

Berdasarkan data dari Badan Pusat Statistik, jumlah penduduk Jakarta tercatat sebanyak 10.187.151 jiwa, $40 \%$ atau 4,5 Juta jiwa diantaranya termasuk kedalam kategori penduduk miskin, cukup ironis penduduk di Ibu Kota hampir setengahnya merupakan penduduk miskin. Kondisi tersebut diperparah dengan kebijakan pemerintah sebelumnya yang dirasakan kurang berpihak kepada masyarakat miskin, salah satunya adalah pelayanan kesehatan bagi masyarakat miskin di Jakarta, bahkan tidak sedikit warga miskin yang meninggal karena ketidakmampuan untuk berobat ke rumah sakit.

Hal tersebutlah yang mendasari JokowiAhok untuk membuat terobosan kebijakan dalam memfasilitasi masyarakat miskin dibidang kesehatan melalui Kartu Jakarta Sehat, sehingga sebagian masyarakat menaruh harapan yang besar terhadap konsep tersebut dan pada akhirnya Jokowi-Ahok terpilih menjadi Gubernur dan Wakil Gubernur Provinsi DKI Jakarta.

Namun pada kenyaatannya kebijakan tersebut tidak selalu berjalan lancar, karena proses serentak sebagai upaya dari realisasi janji politik yang disampaikan oleh Jokowi-Ahok pada saat kampanye politiknya menemui kendala dengan banyaknya masyarakat Jakarta yang menggunakan Kartu Jakarta Sehat (KJS) untuk berobat, sehingga sebagian besar Rumah Sakit rujukan tidak bisa melayaninya. Kasus lainnya muncul ketika bayi Dera Nur Anggraini, bayi yang baru berusia enam hari, meninggal lantaran sakit pada saluran pencernaannya. Ironisnya, Dera meninggal setelah ditolak oleh 10 rumah sakit yang diminta menangani operasinya (www.tempo.co.id).

Fenomena tersebut kemudian memunculkan kembali sebuah sindiran yakni “orang miskin dilarang sakit", padahal puncak pimpinan daerah Provinsi DKI Jakarta telah mengeluarkan kebijakan yang memfasilitasi masyarakat miskin untuk mendapatkan pelayanan kesehatan gratis melaui Kartu jakarta Sehat (KJS). Oleh karena itu, penelitian ini ingin mengurai permasalahan yang terjadi dalam proses implementasi Kartu Jakarta Sehat yang di jalankan oleh Pemerintah Provinsi DKI Jakarta.

\section{METODE}

Dalam hal ini penelitian yang digunakan adalah penelitian studi kasus (case study), yaitu suatu penelitian yang dilakukan untuk mempelajari secara intensif tentang latar belakang keadaan sekarang, dan interaksi lingkungan suatu unit sosial: individu, kelompok, lembaga, atau masyarakat.

Selain itu, dalam mengurai permasalahan coba dipecahkan dengan menggunakan pendekatan Institutional Analisys Development (IAD) (Polski dan Ostrom, 1990). Polski dan Ostrom mengatakan bahwa kelembagaan diartikan sebagai aturan dan rambu-rambu sebagai panduan yang dipakai oleh para anggota suatu kelompok masyarakat untuk mengatur hubungan yang saling mengikat atau saling tergantung satu sama lain.

Penataan institusi dapat ditentukan oleh beberapa unsur, yaitu aturan operasional untuk pengaturan pemanfaatan sumberdaya, aturan kolektif untuk menentukan, menegakkan hukum atau aturan itu sendiri dan untuk merubah aturan operasional serta mengatur hubungan kewenangan organisasi.

\section{HASIL}

Kurang dari seratus hari kerja Pemerintahan Jokowi-Ahok sebagai Gubernur dan Wakil Gubernur Provinsi DKI Jakarta ahirnya merealisasikan program Kartu Jakarta Sehat, sebagai komitmen dari janji politik yang disampaikan pada saat kampanye pemilihan Gubernur dan Wakil Gubernur Provinsi DKI Jakarta, bertepatan dengan peringatan hari pahlawan tanggal 10 November 2012.

Dalam rencananya, seluruh warga Ibu Kota berhak memeroleh kartu ini. Akan tetapi nantinya Pemprov DKI Jakarta hanya menyasar 4,7 juta warga miskin, atau setara dengan 50 persen warga Ibu Kota. 
Jumlah tersebut diberikan secara bertahap. Pada tahap pertama, November hingga Desember, Pemprov DKI Jakarta akan mengeluarkan 3.000 kartu. Adapun kelurahan yang menjadi prioritas utama yang diberikan adalah Tanah Tinggi, Bukit Duri, Manggarai, Pademangan Timur, Marunda, dan Tambora.

Penentuan daerah prioritas tersebut berdasarkan tingkat kepadatan penduduk dan wilayah kumuh. Dengan kartu sehat para pemiliknya dapat berobat gratis di puskesmas, atau rawat inap di rumah sakit umum daerah (RSUD) kelas tiga. Selain tanpa biaya, pasien rawat inap juga akan dirujuk ke RSUD kelas dua apabila ruang di kelas tiga sudah tak lagi tersedia.

Kartu ini dapat diperoleh melalui partisipasi aktif masyarakat mendaftarkan diri ke puskesmas. Kemudian petugas di puskesmas akan mencatat data sesuai KTP, berikut penyerahan bukti serah terima. Untuk mengoptimalkan layanan ini, Pemprov DKI Jakarta bekerjasama dengan berbagai pihak untuk terlibat di dalamnya. Manajemen melalui Jamkesda, sistem diperkuat oleh RSCM, dan tambahan tenaga medis baru dari Fakultas Kedokteran Universitas Indonesia (UI).

Program tersebut dilakukan sebagai bagian dari kebijakan publik yang dilakukan oleh pemerintah Provinsi DKI Jakarta dalam bidang kesehatan. Program ini cukup menarik perhatian publik, karena kebijakan publik di bidang kesehatan untuk sebagian besar negara-negara berkembang masih terabaikan (Walt dan Gilson, 1994). Menurut Kwon et al. (2012) masih banyak negara-negara di Asia Pasifik yang sedang berkembang, pemerintahnya kekurangan dana untuk mendanai sektor kesehatan, khususnya untuk membantu masyarakat golongan lemah dalam membayar biaya kesehatan yang mereka butuhkan. Padahal menurut Deaton (2003) tingkat pendapatan, pemerataan tingkat pendapatan, dan kesehatan merupakan hal penting dalam mencapai kesejahteraan ekonomi. Lebih jauh dia menjelaskan bahwa kesehatan merupakan komponen kesejahteraan, jadi jika kesehatan dipengaruhi oleh kebijakan pemerataan tingkat pendapatan, pajak dan transfer, kebijakan tersebut akan bekerja, tidak saja melalui mekanisme yang sudah umum, misalnya melalui fungsi kesejahteraan sosial pada setiap segmen tingkat pendapatan dan konsumsi masyarakat, tetapi juga melalui tercapainya tingkat kesehatan individu.
Definisi kebijakan publik sebagai the authoritative allocation of values for the whole society atau sebagai pengalokasian nilai-nilai secara paksa kepada seluruh anggota masyarakat (Easton dalam Susilawaty, 2007). Laswell dan Kaplan juga mengartikan kebijakan publik sebagai a projected program of goal, value, and practice atau sesuatu program pencapaian tujuan, nilai-nilai dalam praktek-praktek yang terarah. Pengertian kebijakan publik lainnya juga diungkapkan oleh Anderson dalam Bernier dan Clavier (2011) yang menyatakan bahwa kebijakan publik sebagai $a$ purposive course of action followed by an actor on set an actors in dealing with a problem or matter of concern atau sebagai tindakan yang memiliki tujuan tertentu yang diikuti dan dilaksanakan oleh seorang pelaku atau sekelompok pelaku guna memecahkan suatu masalah yang menjaid perhatian.

\section{PEMBAHASAN}

Dalam konteks negara modern, pelayanan publik telah menjadi lembaga dan profesi yang semakin penting. Ia tidak lagi merupakan aktivitas sambilan, tanpa payung hukum, gaji dan jaminan sosial yang memadai, sebagaimana terjadi di banyak negara berkembang pada masa lalu.

Sebagai sebuah lembaga, pelayanan publik menjamin keberlangsungan administrasi negara yang melibatkan pengembangan kebijakan pelayanan dan pengelolaan sumberdaya yang berasal dari dan untuk kepentingan publik. Sebagai profesi, pelayanan publik berpijak pada prinsip-prinsip profesionalisme dan etika seperti akuntabilitas, efektifitas, efisiensi, integritas, netralitas, dan keadilan bagi semua penerima pelayanan.

Menguatnya embusan globalisasi, demokratisasi, dan desentralisasi membawa peluang sekaligus tantangan tersendiri bagi pelayanan publik, khususnya pelayanan sosial bagi masyarakat.

Hal tersebutlah yang mendasari Jokowi-Ahok untuk membuat sebuah perubahan kebijakan, karena sebuah program kebijakan bisa dilakuan melalui kekuatan politik (political power) yang dilakukan melalui penerimaan aspirasi dari masyarakat. Proses demokrasi yang saat ini terjadi adalah berbagai pihak selalu memanfaatkan masyarakat konstituen sebagai sumber dukungan dalam proses pemilihan untuk memperoleh kekuasaan dan mencapai tujuan yang ingin dicapai oleh para penguasa tersebut. 
Peraturan perundangan (rule) sebagai barang publik (public good) dipandang sebagai suatu hal yang menyangkut kepentingan publik (public interest). Proses politik yang dilakukan oleh JokowiAhok dalam mengawal kebijakan Kartu Jakarta Sehat sebelumnya tidak berjalan mulus, banyak hambatan yang ditemui, mulai dari proeses birokrasi hingga proses penetapan anggaran yang dialokasikan untuk membiayai Kartu Jakarta Sehat tersebut. Proses politik tersebut ditempuh untuk menjadi sebuah landasan hukum dalam bentuk Peraturan daerah. Sehingga Kartu Jakarta Sehat dipandang legal dan tidak bertentangan dengan hukum sebelumnya.

Kebijakan KJS memerlukan dukungan anggaran yang cukup besar, yang salah satusumberpendanaannya berasal dari APBD Provinsi DKI Jakarta. KJS sebagai produk kebijakan desentralisasi daerah harus didukung dengan anggaran yang memadai. Seperti dikemukakan oleh Rinaldi (2012) dan Sasana (2009) kemandirian keuangan daerah merupakan prasyarat penting dalam pelaksanaan otonomi daerah melalui desentralisasinya. Suatu daerah dikatakan mampu untuk melaksanakan otonomi daerah salah satu cirinya terletak pada kemandirian keuangan daerah. Dengan kata lain daerah otonom harus memiliki kewenangan dan kemampuan untuk menggali sumber-sumber keuangan sendiri, mengelola dan menggunakan keuangan sendiri yang cukup memadai untuk membiayai penyelenggaraan pemerintah daerah.

Apabila rule sebagai barang publik atau jasa pelayanan publik sudah dipandang kurang sesuai dengan kepentingan publik, maka sesuai hierarki proses kebijakan maka rule harus senantiasa direvisi, diperbaharui, dan diserasikan dengan perkembangan lingkungan.

Proses sosialisasi yang cukup singkat serta proses pembagian serentak yang dilakukan oleh pemrintah Provinsi DKI Jakarta dalam pembagian Kartu Jakarta Sehat (KJS) berdampak kepada ketidaksiapan pada tingkat pelaksana teknis.

Euforia yang berlebihan dari masyarakat ketika memanfaatkan fasilitas Kartu Jakarta Sehat (KJS) juga menjadi faktor pemicu konflik antara level teknis dengan masyarakat dan puncak pimpinan, sehingga jika dilihat seperti tidak adanya fungsi koordinasi pada beberapa tahapan birokrasi dalam sebuah proses implementasi program Kartu Jakarta Sehat.
Menurut Smith di negara-negara dunia ketiga implementasi kebijakan publik justru merupakan batu sandungan terberat dan serius bagi efektivitas pelaksanaan kebijakan pembangunan di bidang sosial dan ekonomi. Salah satu hambatannya menurut Solichin adalah birokrasi pemerintahan belum merupakan kesatuan yang efektif, efisien, dan berorientasi kepada tujuan. Oleh karena itu, untuk memperoleh pemahaman tentang implementasi kebijakan publik, seharusnya tidak hanya menyoroti perilaku dari lembaga administrasi publik atau benda-benda publik yang bertanggung jawab atas sesuatu program dan pelaksanaannya, namun juga perlu mencermati berbagai jaringan kekuatan politik, ekonomi, dan sosial yang langsung atau tidak langsung berpengaruh terhadap perilaku yang terlibat dalam suatu program dari keluarnya suatu kebijakan publik.

Menurut Jones, dalam melakukan implementasi kebijakan terdapat dua aktor yang terlibat, yaitu pertama, beberapa orang di luar Skema Siklus Kebijakan Publik birokrat yang mungkin terlibat dalam aktivitas implementasi kebijakan, dan kedua, birokrat itu sendiri yang terlibat dalam aktifitas fungsional. Bahkan Mazmanian dan Sabastier dalam Paudel (2009) menambahkan bahwa peran penting dari analisis implementasi kebijakan publik adalah mengidentifikasi variabel-variabel yang mempengaruhi tercapainya tujuan-tujuan formal pada keseluruhan proses implementasi. Di lain pihak, berdasarkan pengalamannya melakukan penelitian di Nigeria, Makinde (2005) menyebutkan bahwa faktor komunikasi antara pihak-pihak yang terkait dengan suatu kebijakan publik merupakan aspek penting dalam keberhasilan implementasi kebijakan tersebut.

Implementasi kebijakan dianggap sebagai $a$ process of moving to ward a policy objective by mean administrative and political steps atau suatu proses tindakan administrasi dan politik. Oleh karena itu. Implementasi kebijakan sesungguhnya bukan hanya sekedar berkaitan dengan mekanisme penjabaran keputusan-keputusan politik ke dalam prosedurprosedur rutin melalui saluran-saluran birokrasi, melainkan lebih dari itu juga berkaitan dengan masalah konflik dan keputusan dari siapa yang memperoleh apa dari suatu kebijakan. 


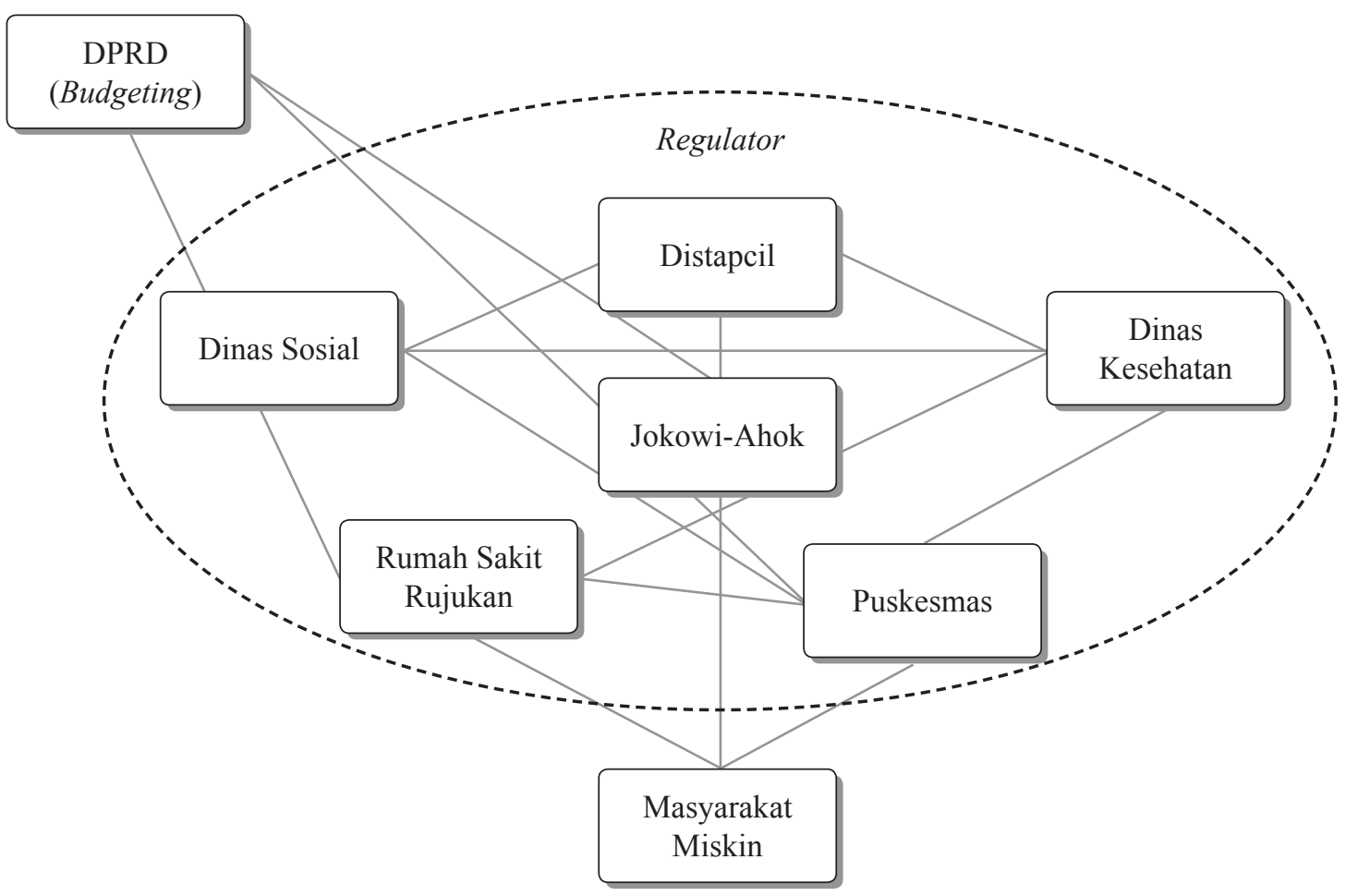

Keterangan: - Arus informasi

Gambar 1. Pattern of Interaction

Kartu Jakarta Sehat

Jika kita mengurai sebuah kebijakan publik yang dikeluarkan melalui Program Kartu Jakarta Sehat dengan menggunakan kerangka Institutional Analisys Development (IAD) yang terdapat dalam buku $A n$ Institutional Framework for Policy Analysis and Design karangan Margaret M. Polski dan Elinor Polski, maka aktor-aktor yang bisa kita identifikasi dalam program tersebut adalah i) Jokowi-Ahok; ii) Dinas Kesehatan; iii) Dinas Kependudukan dan Catatan Sipil; iv) Dinas Kesehatan; v) Puskesmas; vi) Rumah Sakit Rujukan; vii) DPRD; dan viii) Masyarakat miskin (lihat Gambar 1.).

Jokowi-Ahok Sebagai Kepala daerah di Provinsi DKI Jakarta memiliki kekuatan yang cukup besar sebagai pengambil keputusan, keputusan tersebut harus didukung oleh Satuan Kerja Perangkat Daerah (SKPD) terkait, mulai dari Dinas Kesehatan, Dinas Sosial, dan Dinas Kependudukan dan Catatan Sipil, pada tataran teknis sumber informasi diperoleh dari puskesmas yang membuka dan melakukan seleksi pedaftaran untuk pembuatan Kartu Jakarta Sehat
(KJS), pada tataran teknis Rumah Sakit Rujukan menjadi tahap akhir dari proses alur Program Jakarta Sehat (KJS), sedangkan DPRD merupakan proses politis yang harus dilakukan oleh Pemerintah Provinsi DKI Jakarta dalam meneyepakati besaran alokasi anggaran yang dibutuhkan.

Permasalahan yang terjadi saat implementasi kebijakan publik dalam Program Kartu Jakarta Sehat adalah pada tataran teknis, dimana masyarakat yang mengalami euforia untuk bisa berobat gratis tidak bisa ditanggulangi oleh Puskesmas dan Rumah Sakit Rujukan, sehingga muncul konflik dimana rumah sakit tidak bisa melayani para pasien Kartu Jakarta Sehat (KJS). Kondisi tersebut mencerminkan bahwa pelayanan kesehatan yang dilakukan oleh rumah sakit rujukan, yang pada umumnya adalah puskesmas dan rumah sakit daerah masih rendah. Hal ini sesuai dengan beberapa pendapat bahwa pelayanan kesehatan yang diberikan pemerintah lebih buruk dari yang diberikan oleh pihak swasta, seperti dikemukakan oleh Wu dan Ramesh (2009) yang 
dalam penelitiannya menyebutkan ada lima preposisi terkait pelayanan kesehatan, salah satunya adalah preposisi bahwa penyediaan barang dan jasa bidang kesehatan yang dilakukan pihak swasta jauh lebih efisien dibadingkan yang dilakukan oleh pemerintah. Hal senada juga dikemukakan oleh Filmer et al. (2000) yang menyebutkan bahwa menurut para pelaksana bidang kesehatan setuju bahwa pemerintah tidak selalu dapat menyediakan pelayanan kesehatan dengan kualitas yang baik dan efektif dari sisi biaya.

Masih terkendalanya proses implementasi Program kartu Jakarta Sehat coba diurai dengan berbagai upaya, di antaranya yaitu melakukan seleksi mengenai keluhan masyarakat pada tingkat puskesmas; dan memberikan sanksi kepada Rumah Sakit Rujukan yang tidak bersedia untuk melayani masyarakat miskin untuk berobat.

Keterbatasan fasilitas kelas 3 (ekonomi) yang ada rumah sakit rujukan menjadi salah satu faktor utama dalam kasus rawat inap, kemudian kasus berikutnya adalah keterbatasan dokter dalam memeriksa pasien, kemudian permasalah obat yang tersedia di rumah sakit rujukan menjadi alasan-alasan utama yang sering disampaikan oleh pihak rumah sakit rujukan.

Pola perilaku masyarakat yang belum bisa melakukan tahapan proses seleksi, dimana warga masyarakat miskin belum dapat memahami bahwa tidak semua keluhan kesehatan harus langsung diambil tindakan secara medis.

Upaya terakhir dari pemerintah Provinsi DKI Jakarta adalah dengan menyusun rencana pembangunan Rumah Sakit Khusus yang akan menangani masyarakat miskin. Solusi tersebut dirasakan perlu, mengingat peta permasalahan yang saat ini berkembang adalah mengenai keterbatasan fasilitas rumah sakit rujukan. Selain itu Dinas Kesehatan Provinsi DKI Jakarta saat ini telah bekerja sama dengan pihak Kementerian Kesehatan untuk menyusun sebuah call center 119 , di mana pusat layanan tersebut akan memberikan informasi tentang rumah sakit rujukan yang masih tersedia, sehingga para pasien nanti bisa langsung terlayani.

Terlepas dari berbagai permasalahan dalam pelaksanaan penggunaan KJS pada tataran teknis di lapangan, beberapa negara sudah berhasil menerapkan program yang sama dan dirasakan manfaatnya bagi masyarakat golongan lemah. Di Irlandia peluncuran kartu kesehatan terbukti cukup efektif membantu masyarakat miskin dalam memenuhi kebutuhan pelayanan kesehatan yang mereka perlukan (Burke, 2009). Selain di Irlandia, penggunakan kartukesehatan juga dirasakan besar manfaatnya bagi masyarakat miskin di India (Range, 2008). Hasil studi lainnya menunjukkan bahwa program RSBY (Rashtriya Swasthaya Bima Yojana) di India telah membantu meningkatkan kesehatan penduduk miskin, dan pada saat yang sama, perilaku keluarga miskin terhadap pemanfaatan pelayanan kesehatan juga telah berubah menjadi lebih baik, gejala yang disebabkan oleh kehadiran moral hazard (Taneja dan Sihare, 2011). Dengan demikian menjadi begitu besar harapan, bahwa pelaksaan program KJS di Provinsi DKI Jakarta juga akan dapat membantu masyarakat dalam meningkatkan kualitas kesehatannya, khususnya bagi masyarakat ekonomi lemah.

\section{KESIMPULAN}

Berdasarkan hasil penelitian dan pembahasan yang telah diuraikan sebelumnya, maka dapat disimpulkan bahwa Kebijakan Publik untuk bidang kesehatan dengan mengambil studi kasus Kartu Jakarta Sehat (KJS) masih banyak menemui kendala.

Berdasarkan hasil hasil pengamatan dapat disimpulkan bahwa penerapan Kartu Jakarta Sehat (KJS) memang sangat dibutuhkan oleh masyarakat miskin, sehingga dalam proses implementasinya harus terus dilakukan perbaikan-perbaikan baik dari sisi regulasi, kapasitas dan proses sanksi yang diterapkan, sehingga upaya pemerintah untuk menjalankan kewenangan dalam optimalisasi pelayanan publik bidang kesehatan bisa dicapai. Proses euforia masyarakat miskin untuk berobat gratis dengan menggunakan Kartu Jakarta Sehat (KJS) harus mulai diredam, karena keterbatasan sarana dan prasaran medis yang ada masih cukup terbatas, sedangkan pemegang kartu jakarta sehat sudah lebih dari 10.000 dan kapasitasnya akan terus ditingkatkan, sehingga 4,5 juta jiwa penduduk miskin bisa mengakses pelayanan berobat gratis.

Keterbatasan fasilitas medis berupa Puskesmas dan Rumah Sakit Rujukan yang saat ini tersedia coba dipecahkan dengan melakukan perencanaan untuk dibangunnya rumah sakit khusus yang akan melayani pengobatan masyarakat miskin, disamping upaya yang saat ini telah dilakukan dengan membuat call center 119 supaya pendistribusian pasien Kartu Jakarta Sehat (KJS) menjadi lebih merata. 
Upaya-upaya tersebut dilakukan guna mencapai sebuah tujuan dari pemerintah yakni memberikan pelayan terbaik kepada maysarakat yang sebelumnya belum pernah merasakan pengobatan gratis dari pemerintahan sebelumnya.

Proses tersebut tercapai sebagai bagian dari kompromi politik yang dilakukan oleh Jokowi-Ahok pada saat kampanye dan direalisasikan setelah terpilih menjad Gubernur dan Wakil Gubernur Provinsi DKI Jakarta.

\section{DAFTAR PUSTAKA}

Badjuri. H. Abdulkahar, Yuwono. Teguh, Admin, M. Pol, 2002. Kebijakan Publik: Konsep dan Strategi. Semarang: Fisip Universitas Diponegoro.

Bernier, N. F., and Clavier, C. 2011. Public Health Policy Research: Making the Case for a Political Science Approach. Health Promotion International, 26(1): 109-116.

Burke, Sara. 2009. Boom to Bust: Its Impact on Irish Health Policy and Health Services. Irish Journal of Public Policy, 2(1).

Darmawan Triwibowo, D., Muhajir, M., \& Mutasya, T. 2010. Perluasan Inovasi Kebijakan Sosial di Tingkat Lokal; Studi Kasus Kebijakan Kesehatan: Peran Faktor Kunci dan Peluang bagi Perbaikan Proses. Policy Paper Perkumpulan Prakarsa, Oktober.

Deaton, Agus. 2003. Health, Inequality, and Economic Development. Journal of Economic Literature, XLI March: 113-158.

Filmer, D., Hammer, J. S., adn Pritchett, L. H. 2000. Weak Links in the Chain: A Diagnosis of Health Policy in Poor Countries. The World Bank Research Observer, 15(2): 199-224.

Makinde, Taiwo. 2005. Problems of Policy Implementation in Developing Nations: The Nigerian Experience. Journal of Social Sciences, 11(1): 63-69.

Malden, Wu, A., \& Ramesh, M. 2009. Health Care Reforms in Developing Asia: Propositions and Realities. Development and Change, 40(3): 531-549.
Kwon, S., et al. 2012. Direct household payments for health services in Asia and the Pacific: Impacts and Policy Options. Asia Pacific Observatory on Health Systems and Policies, February.

Paudel, Narendra Raj. 2009. A Critical Account of Policy Implementation Theories: Status and Reconsideration. Nepalese Journal of Public Policy and Governance, XXV(2): 36-54.

Polski, Margaret M. \& Elinor, Ostrom. 1990. An Institutional Framework for Policy Analysis and Design.

Range, Jackie. 2008. India's Poor Get Health Care in a Card. The Wall Street Journal, August(26).

Rinaldi. Udin. 2012. Kemandirian Keuangan Dalam Pelaksanaan Otonomi Daerah. Jurnal EKSOS, 8(2): $105-113$.

Septyandrica, Chitra Retna \& Ardhyanti, Ermy. 2009. Inisiatif Daerah dalam Mengembangkan Jaminan Kesehatan: Pola Pembelajaran. Working Paper PATTIRO. PATTIRO.

Silfia, Hanani \& Abdul Aziz, Rahima. 2009. Rekonstruksi dan usaha penyelamatan tradisi lokal era pasca sentralisme di Indonesia. Malaysian Journal of Society and Space, 5(2): 68 - 81.

Sasana, Hadi. 2009. Peran Desentralisasi Fiscal Terhadap Kinerja Ekonomi Kabupaten/ Kota Privinsi Jawa Tengah. Jurnal Ekonomi Pembangunan, 10(1): 103-124.

Susilawaty, Susy. 2007. Analisis Kebijakan Publik Bidang Keselamatan Dan Kesehatan Kerja Di Kota Tasikmalaya. Semarang: Program Pascasarjana Universitas Diponegoro.

Taneja, P. W., \& Sihare, H. 2011. Prospec \& Consecuences of Micro insurance to Eradicate Health Problems in The Below Poverty Line (BPL) Population: Empirical Evidence From India. Italian Journal of Public Health, 8(4).

Walt, Gill \& Gilson, Lucy. 1994. Reforming The Health Sector in Developing Countries: The Central Role of Policy Analysis. Health Policy Planning, 9(4):353-370. 